\title{
IDIOMATIC EXPRESSION TRANSLATION STRATEGY IN RHONDA BYRNE'S BOOK THE MAGIC
}

\author{
Fitriyah Fitriyah \\ Universitas Bina Sarana Informatika, Jakarta, Indonesia \\ E-mail: fitriyah.fit@bsi.ac.id
}

Received: 27 October 2020

Accepted: 05 December 2020

\begin{abstract}
One of the problems in translation is idiom. Idiomatic expressions are unique because their structures cannot always be translated literally and even tend to form new meanings. This research aims to analyze the strategy of English idioms translation in Rhonda Byrne's book The Magic which was translated into Indonesian entitled The Magic by Susi Purwoko and to find out the most dominant strategy used by translator. This research is a qualitative descriptive study. The data are English idioms and their translation in Indonesian. There are 48 data. Those are analyzed based on Baker's Idiom translation strategies. They are (1) using an idiom of similar meaning and form, (2) using an idiom of similar meaning but dissimilar, (3) Translation by paraphrase. The result shows that there are three strategies of English idioms translation in Rhonda Byrne's book The Magic. They are (1) using an idiom of similar meaning and form (15\%), (2) using an idiom of similar meaning but dissimilar (31\%), (3) Translation by paraphrase (54); and the most dominant strategy is a translation by paraphrase.
\end{abstract}

Keywords: idiom, Source Language (SL), Target Language (TL), idiom translation strategy.

\section{Introduction}

Nowadays, translation activities are increasingly attracting many people from various disciplines. The translation is an alternative activity that gets the attention of the public because it is hoped that translation will be able to bridge problems that arise due to different languages. The translation is becoming increasingly important because most texts on scientific and technological information originate from developed countries and are written in English or other foreign languages. Only with translation can people know and understand the contents of the text.

Translation demands a deep understanding of both grammar and culture. Translators need to know the rules of a language as well as the habits of the people who speak it. In addition, even for the most experienced professionals, confusion and frustration are familiar feelings. Every language sits inside a defined structure with its own agreed upon rules (Saragih, 2020). When we are communicating with people from different cultures, it is best to know what is appropriate in their culture and act with regard to that, so as to avoid misunderstandings caused by culture differences (Fitriyah, Emzir, \& Ridwan, 2019).

Several problems are related to the mastery of source language (SL) and target language (TL). They become very complicated because the lack of mastery of SL (English) and TL will cause the translator to be unable to understand the message contained in SL properly, and 
the lack of mastery of TL (Indonesian) will result in the translator having difficulty expressing the message to the public.

Therefore, it is not surprising to say that translating is difficult and complicated. In addition to having special skills, a translator must also master linguistic and non-linguistic aspects well. The linguistic aspect includes the source language (SL) and the target language (TL), while the non-linguistic aspect includes the cultural aspects of the source language and target language. The translation technique is expected to be a solution to the translation problems faced by translators.

In this study, the researcher chose a popular book, which is a type of book that deals with certain issues that are interesting to be listened to and known by the general public. Due to the wide variety of popular books, a translator must be able to transfer messages from SL into TL appropriately, especially in translating idioms. For example, the idiom to follow someone's which means walking straight on, to hand in a request means submitting a request, his fingers are all thumbs which means he is very awkward. For example, idiom to follow one's which means berjalan lurus terus, to hand in a request which means mengajukan suatu permohonan, his fingers are all thumbs which means ia sangat canggung, and so on.

Among the many popular books published to date, Rhonda Byrne's book The Magic, which was released in 2012, is her third book (still in The Secret book series), after her first book, The Secret, then her second book The Power of The Secret. The third book is The Magic. The researcher chose this book because it is the newest book by Rhonda Byrne. The Magic is one of the popular books that received a warm welcome and is quite taken into account by readers. This is because the themes discussed in the book are very interesting, as well as a personal experience of the author. Besides that, the use of idiom expressions in the book is quite diverse so that researchers are interested in examining the translation.

In this regard, one of the most problems in translation is idioms. The Idiom expressions are unique because their structures cannot always be translated literally and even tend to form new meanings. In addition, idiom expressions have special characteristics, namely oddities or deviations from the usual (anomaly), regarding the problem of the meaning of the idiom. Although it is unique and tends to be difficult, the use of idioms is almost inevitable. The idiom used can take many forms.

From the problems set out above, this study aims to describe and analyze the form of English idioms in the book The Magic.

\section{Literature Review}

Translation consists of transferring the meaning of the first language into the form of the second language by paying attention to its semantic structure. Translation involves two languages, the source language (SL) and the receiving language (TL) and the act of translation is an act of producing the meaning of messages, statements, utterances, and BS text styles into BP text (Verity \& Larson, 1986)

Bell (1991: 6) argues that translation is the replacement of a representation of the same text in a second language. Text in two different languages can be the same in different degrees (in whole or in part). Bell further adds that translation is a replacement for the representation of the same text into a second language text, especially those related to similarity in context, semantics, grammar, lexical, and so on, and at different levels (wordfor-word, phrase-for-phrase, sentence-for-sentence). Due to the different perspectives of 
experts in defining translations, in principle, they agree on the consideration of meaning as the most important consideration.

Next, another thing that is no less important is language style. In translation, a language style is not the same as that in the field of literature, according to Nababan (2003). The language style in translation is more focused on the official level of the target language form adjusted to the official level of the source language form. In line with Nababan, Kridalaksana (in Nababan, 2003) says that the translator is a source of transferring a message from SL to TL by first expressing its meaning and then the style of the language. This opinion seems to be embraced more by the translators because this definition can better represent things that are often encountered by translators when carrying out translation activities.

Before carrying out a translation, it is necessary to select a procedure or strategy of translation. It is necessary to know whether the message can be understood or not. To oversee the transfer of the meaning and message of the source language (SL) into the target language (TL), the first thing to know is the meanings that are related to words, word formation, and word sequences that form various units from the smallest units to the text overall.

When reading a translated text, various problems are found in understanding the contents of the text. This is due to various factors, such as differences in the culture of the author of the text and the readers, which can significantly result in the interpretation or insight of the concept of words or terms used by the author. Sometimes readers also encounter words or terms that are considered foreign by readers so that they do not understand the meaning contained in them. Therefore, in the process of transferring the contents of the text, one should pay attention not only to the structure of the sentence but also to the understanding of the meaning of the word or term as a whole.

According to Hatim and Munday (2004:6), the translation process that produces a translation product cannot be separated from the surrounding social and cultural context. Matters related to cognitive, linguistic, visual, cultural and ideological phenomena are an inseparable part of the translation process and product. Thus, translation does not only transfer messages from one language to another, but also considers social and cultural factors that exist in the text of the source language and the text of the target language.

Bell (1991:20) divides the translation process that occurs in human memory into 2 stages, namely the analysis stage and the synthesis stage. At the analysis stage, the translator tries to see the source text and understands the text from a linguistic and nonlinguistic perspective. This activity is carried out by reading, understanding, and analyzing the SL text, while linguistic analysis covers various levels, starting from the highest level to the lowest level, or vice versa. At the synthesis stage, the translator combines the semantic image into the TL text or more clearly depicted the meaning of SL into TL. This process occurs in the translator's brain or is the inner process of the translator.

There are language criteria which have a direct influence on translation principles. The point is that in translating a text, a translator must consider the components of meaning, grammatical patterns, and sentences as a whole because all these forms are identified differently in other languages and all expressed with different meanings or functions.

Meaning is studied from the first language form to the second language form to see the semantic structure. The meaning that is transferred must be continuous (constant) and only the form changes. To produce an effective translation, what must be paid attention to is to find the meaning of SL and use the TL forms which express that meaning in a natural way. 
By knowing the type of translation to be used in translating, a translator is expected to be able to transfer the intended message or meaning properly. To get a good translation result, a translator must pay attention to every process that must be passed in the translation process itself.

Various theories and opinions regarding the translation method can be obtained from various sources. One of them is Larson (Verity \& Larson, 1986), stating that the translation method is categorized into two types, namely (1) literal translation and (2) idiomatic translation. The literal translation is also called form-based translation, which is the translation process by following the form of the source language. For example, SL: How are you? TL: Bagaimana kamu? Meanwhile, idiomatic translation is also called meaning-based translation. This type of translation focuses more on the fairness of its equivalence in the target language, so that the translation product is expected not to reflect the source language, but another form of original writing with the same idea content as the source language. For example, SL: cats and dogs' rain. TL: hujan deras.

Molina and Albir said that the translation method justifies the entire translated text, while the translation technique focuses more on analyzing the components of the language and classifying all of the components so that an appropriate equivalent is found in Hartono, (2020: 1). In this connection Molina and Albir explain five basic characteristics of translation techniques: a) Translation techniques affect the translation results, b) Translation techniques compare SL with TL. c) Translation techniques affect the smallest units of text, for example, words, phrases, and sentences. d) Translation techniques are natural and contextual discursive (logical). e) Translation techniques are functional.

Newmark (in Hartono, 2020) proposes eight translation methods that are grouped into two parts. The first part (four methods: word-for-word, literal, faithful, and semantic) emphasize the source text and the second part (four methods: adaptation, free, idiomatic, and communicative) tend to emphasize the target text. All eight methods of translation lead finally translators to have two strategies of translation: foreignization and domestication or both are well known as translation ideology. If the translator tends to use four of eight methods emphasizing the source language, he tends to keep the foreignization ideology and vice versa.

Many translation experts define this translation method. One of them is Larson who said that idiomatic translation uses the natural grammatical forms and lexical choices in the target language. A truly idiomatic translation does not look like a translation, it is like a native word. As if the writing is directly written by the original or native speakers. In terms of idiomatic translation usage, a good translator will translate the text idiomatically, searching equivalent as naturally as possible, replacing the original idioms with the target idioms. In short, in this case, idioms are translated into idioms, proverbs to proverbs, metaphors to metaphors, figuratively to figuratively, personification to personification, assonance to assonance, and alliteration to alliteration (Hartono, 2020:47).

Newmark (in Hartono, 2020) adds that idiomatic translation reproduces messages in the target language text with expressions that are more natural and familiar than the sourcelanguage text. Meanwhile, Baker (1992:63) clarifies the above opinion by stating, "in the case of idioms, often carry meanings which cannot be deduced from their individual components.

From these opinions, it can be said that the meaning of idioms cannot be drawn from the meaning of the lexical elements that make them up according to the prevailing 
grammatical rules. The meaning of the idiom must be seen as a unit, not from each of the components that make up the idiom.

Seeing from the shape, idioms are classified based on different levels of semantic units and differences in their structure so that it seems clearer that idioms can be in the form of expressions, grammatical constructions, and phrases.

Regarding the structure, Baker (1992) says, "Idioms (and fixed expressions)... are frozen patterns of language which allow a little or no variation in form, and in the case of idioms, often carry meaning which cannot be deduced for their individual components. This definition explains that there are two important things in studying idioms. The first is the structure of the idiom that cannot change, the second is the meaning of the idiom which must be seen as a unified whole. For example: the word carry the ball. It consists of the elements form carry and the ball which form a single unit. This definition implies that (1) these elements cannot be changed or replaced by synonyms or other words which become an extension or even a narrowing of the meaning of the word. For example, the word ball is replaced by tennis ball so that it becomes carry the tennis ball. The phrase carry the ball has a figurative meaning, while carry the tennis ball has real meaning. (2) related to the meaning, an idiom cannot be translated word for word but must be seen as a whole from its constituent elements.

According to Baker (1992:71), there are four idiom translation strategies. They are (1) using an idiom of similar meaning and form. This strategy involves using an idiom in the target language which conveys roughly the same meaning as that of the source language idiom, and in addition, consists of equivalent lexical items. (2) using an idiom of similar meaning but dissimilar. It is often possible to find an idiom in the target language which has a similar meaning to that of the source idiom or expression, but which consists of different lexical items (3) Translation by paraphrase. This is by far the most common way of translating idioms when a match can not be found in the target language or when it seems inappropriate to use idiomatic language in the target text because of differences in stylistic preferences of the source and target language, we may find the paraphrase (4) Translation by omission.

\section{Research Method}

This research used a qualitative approach and descriptive analysis method to analyze the idiom translation strategies in Rhonda Byrne's book The Magic and the translation book entitled The Magic which was translated by Susi Purwoko. This research is basic research because it only aims to understand a problem without leading to finding ways to solve problems with actions that are practical applications (Sutopo,1996:109). In general, qualitative research uses a basic strategy in the form of case studies in the form of single case because in this study the nature of the data under study consists of only one character (as an idiom).

The researcher used the strategy of idiom translation of Baker (1992). They are (1) using an idiom of similar meaning and form. This strategy involves using an idiom in the target language which conveys roughly the same meaning as that of the source language idiom, and in addition, consists of equivalent lexical items. (2) using an idiom of similar meaning but dissimilar. It is often possible to find an idiom in the target language which has a similar meaning to that of the source idiom or expression, but which consists of different lexical items (3) Translation by paraphrase. This is by far the most common way of translating idioms when a match can not be found in the target language or when it seems 
inappropriate to use idiomatic language in the target text because of differences in stylistic preferences of the source and target language, we may find the paraphrase (4) Translation by omission.

To test the validity and correctness of the data, data triangulation, and method triangulation were used. Meanwhile, the analysis technique uses interactive analysis techniques. This analysis model has three main components, namely data reduction, data presentation, and drawing conclusions or verification.

\section{Results and Discussion}

In this study, the researcher analyzed the data based on the original text (The Magic by Rhonda Byrne), called SL (source language) and the translated text (The Magic that was translated by Susi Purwoko), called TL (target language). The findings are shown below:

Table 1: The Idioms Expression Translation of The Magic

\begin{tabular}{|l|l|c|c|}
\hline No & \multicolumn{1}{|c|}{ Strategy } & Amount & Percentage (100\%) \\
\hline 1 & Using an idiom of similar meaning and form & 7 & $15 \%$ \\
\hline 2 & $\begin{array}{l}\text { Using an idiom of similar meaning but } \\
\text { dissimilar form }\end{array}$ & 15 & $31 \%$ \\
\hline 3 & Translation by paraphrase & 26 & $54 \%$ \\
\hline \multicolumn{1}{|c|}{ Total amount } & 48 & $100 \%$ \\
\hline
\end{tabular}

Based on the findings in table 1, the idioms expression translation are divided into several strategies as follows:

\section{(a) Using an idiom of similar meaning and form}

This strategy involves using an idiom in the target language which conveys roughly the same meaning as that of the source language idiom, and in addition, consists of equivalent lexical items (Mona Baker, 1992). Based on the table 1 there are 7 data that using similar meaning and form. The examples are follows:

(1) SL: The magical power of gratitude turns your life into gold (Byrne, 2012a: 16)

TL: Daya ajaib dari syukur mengubah hidup Anda menjadi emas (Byrne, 2012b:16)

(2) SL: The more gratitude you have, the more abundance you magnetize (Byrne, 2012a:7)

TL: Semakin banyak syukur yang Anda miliki, semakin banyak kelimpahan yang Anda tarik (Byrne, 2012b:8)

(3) SL: You reap what you sow, you get what you give (Byrne, 2012a:7)

TL: Anda memanen apa yang Anda tanam, Anda mendapatkan apa yang Anda beri (Byrne, 2012b:8)

In translation cases, the translator usually gets a problem when translating text from the source language into the target language especially in translating idioms. So, the translator usually finds the similar words that have a close meaning and form with the sourse language. 


\section{(b) Using an idiom of similar meaning but dissimilar form}

Baker said that it is often possible to find an idiom in target language which has similar meaning to that of the source idiom or expression, but which consists of different lexical items. Based on the findings in table 1 there are 15 data that using a similar meaning but dissimilar form. The examples are follows:

(1) SL : I don't get along with my parents (Byrne, 2012a:7)

TL : Aku tidak akur dengan orangtuaku (Byrne, 2012b:7)

(2) SL: I think I'm coming down with something (Byrne, 2012a:7)

TL: Aku rasa aku akan mengalami sesuatu yang buruk_(Byrne, 2012b: 7)

(3) SL: One week after another, one day after another, great news pours in! (Byrne, 2012a:137)

TL : Dari minggu ke minggu, hari ke hari, kabar-kabar gembira membanjiri! (Byrne, 2012b:150)

There are language criteria which have a direct influence on translation principles. The point is that in translating a text, a translator must consider the components of meaning, grammatical patterns, and sentences as a whole, because all these forms are identified differently in other languages and all expressed with different meanings or functions. That is why, the translator will use the words that have a similar meaning, although have dissimilar form.

\section{c) Translation by paraphrase}

This is the most common way of translating idioms when a match can not be found in the target language or when it seems inapprop riate to use idiomatic language in the target text because of differences in stylistic preferences of the source and target language, we may find the paraphrase. Based on the table 1 there are 26 data that use paraphrase. The examples are follows:

1) SL: But somehow as we grew into adults, responsibilities, problems, and difficulties took their toll on us, (Byrne, 2012a:2)

TL: Tetapi, ketika kita tumbuh dewasa, tanggung jawab, masalah, dan kesulitan membuat kita tidak bahagia (Byrne, 2012b:2)

2) SL : Maybe they were someone you didn't even know, and they appeared in your life briefly, performing a random act of kindness that touched you to the core. (Byrne, 2012a:118)

TL: Mungkin dia adalah seseorang yang bahkan tidak Anda kenal, yang muncul sesaat di dalam hidup Anda, melakukan tindak kebaikan yang sangat menyentuh Anda. (Byrne, 2012b:130)

3) SL: But then reality of having to work harder to pay for those pleasures would sweep over me (Byrne, 2012a:11)

TL : Tetapi realita harus bekerja lebih keras untuk membayar kenikmatan itu membuat saya semakin stress. (Byrne, 2012b:12) 
When reading a translated text, various problems are found in understanding the contents of the text. This is due to various factors, such as differences in the culture of the author of the text and the readers, which can significantly result in the interpretation or insight of the concept of words or terms used by the author. Sometimes readers also encounter words or terms that are considered foreign by readers so that they do not understand the meaning contained in them. Therefore, in the process of transferring the contents of the text, one should pay attention not only to the structure of the sentence, but also to the understanding of the meaning of the word or term as a whole.

From these findings, it can be said that the meaning of idioms cannot be drawn from the meaning of the lexical elements that make them up according to the prevailing grammatical rules. The meaning of the idiom must be seen as a unit, not from each of the components that make up the idiom. The idiomatic translation reproduces messages in the target language text with expressions that are more natural and familiar than the source language text.

\section{Conclusion}

Based on the research, there are 48 idioms in Ronda Byrne's book The Magic. From the four Baker's idiom translation strategies, the researcher found only 3 strategies that used by the translator in translating idiom. They are (1) using an idiom of similar meaning and form (15\%), (2) using an idiom of similar meaning but dissimilar (31\%), and (3) Translation by paraphrase (54\%).

Based on the findings above, the most dominant strategy used in The Magic is translation by paraphrase, because it is easier to make paraphrase when we do not find the appropriate or similar meaning in the target text.

\section{References}

Bell, R. T.-. (n.d.). (1991). Translation and Translating_ Theory and Practice. https://www.academia.edu/38460208/Translation_and_Translating_Theory_and_Pr actice.

Byrne, R. (2012a). The Magic, (86400), 16-19, 133,. https://febs.onlinelibrary.wiley.com/ doi/full/10.1002/1873-3468.13747.

Byrne, R. (2012b). The Magic (terjemahan). Jakarta: Gramedia Pustaka Utama.

Fitriyah, F., Emzir, E., \& Ridwan, S. (2019). Cultural Values of Politeness in Efl Classroom: a Study of Etnography of Communication. Language Literacy: Journal of Linguistics, Literature, and Language Teaching, 3(2), 207-216. https://doi.org/10.30743/II.v3i2.1965

Hartono, R. (2020). TRANSLATION The Essential Reference for Translators. https://www.researchgate.net/publication/337632508_Product_Label_Translation_i n_Indonesia_Mistakes_Quality_and_Solutions.

Hatim, B., \& Munday, J. (2004). Translation: An advanced resource book (Vol. 53). https://doi.org/10.1017/CBO9781107415324.004

Mona Baker. (1992). In Other Words A Coursebook on Translation. https://www.academia.edu/5675886/In_Other_Words_A_Coursebook_on_Translatio n_Mona_Baker.

Nababan, M. (2003). Teori Menerjemah Bahasa Inggris. Yogjakarta: Pustaka Pelajar.

Saragih, A. E. (2020). The Translation of Phrasal Verbs in Thirteen Reasons Why. Language Literacy: Journal of Linguistics, Literature, and Language Teaching, 4(1), 160-167. 
https://doi.org/10.30743/II.v4i1.2307

Sutopo, H. . (n.d.). Metodologi Penelitian untuk Ilmu-ilmu Sosial dan Budaya. Surakarta: UNS Press.

Verity, D. P., \& Larson, M. L. (1986). Meaning-Based Translation: A Guide to Cross-Language Equivalence. The Modern Language Journal, 70(1), 95. https://doi.org/10.2307/328112 